\begin{tabular}{|l|l|l|}
\hline \multicolumn{2}{|c|}{ PublisherInfo } \\
\hline \hline PublisherName & $:$ & BioMed Central \\
\hline \hline PublisherLocation & $:$ & London \\
\hline \hline PublisherImprintName & $:$ & BioMed Central \\
\hline \hline
\end{tabular}

\title{
Do HIV patients fare well in intensive care units?
}

\begin{tabular}{||l|l|l||}
\hline \multicolumn{2}{|c||}{ ArticleInfo } \\
\hline \hline ArticleID & $:$ & 4204 \\
\hline \hline ArticleDOI & $:$ & $10.1186 /$ ccf-2000-5379 \\
\hline \hline ArticleCitationID & $:$ & 5379 \\
\hline \hline ArticleSequenceNumber & $:$ & 63 \\
\hline \hline ArticleCategory & $:$ & Paper Report \\
\hline ArticleFirstPage & $:$ & 1 \\
\hline \hline ArticleLastPage & $:$ & 3 \\
\hline \hline & $:$ & RegistrationDate : 2000-6-6 \\
ArticleHistory & $:$ & OnlineDate \\
\hline \hline ArticleCopyright & $:$ & Current Science Ltd2000-6-6 \\
\hline \hline ArticleGrants & $:$ & \\
\hline \hline ArticleContext & $:$ & 1305422 \\
\hline \hline
\end{tabular}


Naresh Ramakrishnan, ${ }^{\text {Aff1 }}$

Aff1 The Royal Melbourne Hospital, Australia

\section{Keywords}

Critical care, HIV, intensive care, prognosis, survival

\section{Comments}

In an age of increased economic rationalization and patients? autonomy, a clinician is often faced with the challenge of resource allocation. This article provides some insight and justification for the provision of life-sustaining treatments for patients infected with human immunodeficiency virus (HIV). This retrospective review covers the years from 1992 to 1995, a period that predates the introduction of several powerful antiretroviral drugs into the general community. In this series (largest to date) of patients admitted to the ICU with HIV, the overall survival rate of discharge-to-home was a staggering $63 \%$. This figure may be an underestimate, given the efficacy of current antiretroviral strategies or alternatively we may be seeing sicker patients in intensive care. It was disappointing to note that only $27 \%, 18 \%, 13 \%$ and $11 \%$ of this cohort were alive at 1,2, 3 and 4 years after discharge respectively. The use of mechanical ventilation, infection with pneumocystis carinii pneumonia (PCP), and lower levels of serum albumin correlated with higher hospital mortality. Interestingly, neither a history of opportunistic infection or malignancy nor the presence of chronic renal, liver or respiratory disease affected hospital outcome.

\section{Introduction}

Despite the availability of better strategies to decrease the viral load, and consequently the immunosuppression of an individual with HIV, infections are more common and are associated with a higher morbidity and mortality in this group. The provision of intensive care to these patients is challenging, both biologically and emotionally. The clinician requires good data to offer an informed choice to the individual with HIV. This study attempts to provide a sound basis for that.

\section{Methods}


- Retrospective, observational study in 394 adult, HIV infected, patients requiring intensive care

- All patients were admitted to the ICU at San Francisco General Hospital, California, USA, between 1992 and 1995

- Patients were identified through a billing system and charts were reviewed retrospectively

- Survival curves were calculated using the Kaplan-Meier method and logistic regression analysis was used to identify variables that were predictive of death during hospitalization

\section{Results}

The mean APACHE II score was 16 (range 0-37), the mean albumin level was $25 \mathrm{~g} / \mathrm{L}$ (range 10-45) and the mean $\mathrm{CD}^{+}$cell count was 108 cells $/ \mu \mathrm{L}$ (median 52 , range $0-960$ cells). Sixty-seven percent of patients were on PCP prophylaxis, and 52\% had prior antiretroviral therapy.In total, 245 of the 394 patients (55\%) required mechanical ventilation and $21 \%$ had PCP. Overall, 24\% died in ICU, $13 \%$ survived ICU but died in hospital, 63\% survived hospitalization.Multiple logistic regression analysis found that the use of mechanical ventilation (risk ratio $1.37,95 \% \mathrm{CI} 1.08-1074, P=0.01$ ), $\mathrm{CD} 4^{+}$cell count $(<50$ cells $/ \mu \mathrm{L})$, lower serum albumin $(<25 \mathrm{~g} / \mathrm{L})$ and current PCP correlated with higher hospital mortality.

\section{Additional information}

The $\mathrm{CD} 4^{+}$cell count is often used as a marker of the level of immunosuppression with $<150$ marking immunosuppression and $<50$ marking profound immunosuppression. It is important tonote that is a retrospective review, and there are improved antiretroviral strategies available to the clinician today.

\section{References}

1. Nickas G, Wachter RM: Outcomes of intensive care for patients with human immunodeficiency virus infection. Arch Intern Med. 2000, 160: 541-547.

This PDF file was created after publication. 